\title{
Analysis of simple sequence repeat markers linked with blast disease resistance genes in a segregating population of rice (Oryza sativa)
}

\author{
S. Ashkani ${ }^{1}$, M.Y. Rafii ${ }^{1}$, M. Sariah ${ }^{2}$, A. Siti Nor Akmar' ${ }^{2}$, I. Rusli ${ }^{3}$, \\ H. Abdul Rahim ${ }^{3}$ and M.A. Latif ${ }^{1}$ \\ ${ }^{1}$ Department of Crop Science, Faculty of Agriculture, \\ Universiti Putra Malaysia, Serdang, Selangor, Malaysia \\ ${ }^{2}$ Institute of Tropical Agriculture, Universiti Putra Malaysia, \\ Serdang, Selangor, Malaysia \\ ${ }^{3}$ Malaysian Nuclear Agency, Bangi, Kajang, Selangor \\ Corresponding author: M.Y. Rafii \\ E-mail: mrafii@putra.upm.edu.my
}

Genet. Mol. Res. 10 (3): 1345-1355 (2011)

Received February 15, 2011

Accepted February 23, 2011

Published July 6, 2011

DOI 10.4238/vol10-3gmr1331

\begin{abstract}
Among 120 simple sequence repeat (SSR) markers, 23 polymorphic markers were used to identify the segregation ratio in 320 individuals of an $\mathrm{F}_{2}$ rice population derived from Pongsu Seribu 2, a resistant variety, and Mahsuri, a susceptible rice cultivar. For phenotypic study, the most virulent blast (Magnaporthe oryzae) pathotype, P7.2, was used in screening of $\mathrm{F}_{2}$ population in order to understand the inheritance of blast resistance as well as linkage with SSR markers. Only 11 markers showed a good fit to the expected segregation ratio $(1: 2: 1)$ for the single gene model (d.f. $=1.0, \mathrm{P}<0.05)$ in chi-square $\left(\chi^{2}\right)$ analyses. In the phenotypic data analysis, the $\mathrm{F}_{2}$ population segregated in a 3:1 (R:S) ratio for resistant and susceptible plants, respectively. Therefore, resistance to blast pathotype P7.2 in Pongsu Seribu 2 is most likely controlled by a single nuclear gene. The plants from $\mathrm{F}_{2}$ lines that showed resistance to blast pathotype P7.2 were linked to six alleles
\end{abstract}


of SSR markers, RM168 (116 bp), RM8225 (221 bp), RM1233 (175 bp), RM6836 (240 bp), RM5961 (129 bp), and RM413 (79 bp). These diagnostic markers could be used in marker assisted selection programs to develop a durable blast resistant variety.

Key words: Rice blast (Magnaporthe oryzae); Disease resistance; Simple sequence repeat markers; $\mathrm{F}_{2}$ population

\section{INTRODUCTION}

Rice blast, caused by the pathogenic fungus Magnaporthe oryzae, is one of the important rice diseases, causing great damage to rice yield because of its wide distribution and destructiveness under favorable conditions $(\mathrm{Ou}, 1980)$. Blast can be managed by providing multi-genetic resistance against a wide spectrum of blast races in rice cultivars (Correa-Victoria et al., 2002). This can be done by pyramiding the resistance genes into cultivar or rice varieties. Resistance to blast has been classified into complete and partial resistance (Wang et al., 1994). Complete resistance is a qualitative character and race specific controlled by a major gene. Meanwhile, partial resistance is a quantitative character and non-race specific, which is controlled by many genes known as quantitative resistance loci (Koizumi, 2007). However, if the resistance is highly partial, it can also be controlled by a major gene and is race specific. The use of molecular markers in many aspects of rice studies has been increasing considerably. Microsatellites or simple sequence repeats (SSRs) are widely used in rice genetic studies. SSRs are highly polymorphic genetic markers and because of their widespread distribution in the genome, high allelic diversity and inherent potential have become a valuable source of genetic markers. SSR markers have been applied to analyze diversity (Cho et al., 2000; Harrington, 2000) and to locate genes and quantitative trait loci (QTLs) on rice chromosomes (Zou et al., 2000; Bres-Patry et al., 2001; Moncada et al., 2001). Several microsatellite markers with publicly available databases closely linked with the $P i-b, P i-k^{h}$ and $P i-t a^{2}$ resistance genes have been identified (Fjellstrom et al., 2002). To date, more than 40 major blast resistance genes have been identified (Pan et al., 1999; Chauhan et al., 2002; Berruyer et al., 2003; Sallaud et al., 2003; Liu et al., 2004; Zhu et al., 2004). The presence of markers tightly linked to resistance genes will allow selection and maintenance of the desirable resistant genotypes in breeding process (Hittalmani et al., 1995; Naqvi and Chattoo, 1996). The objective of our study was to analyze SSR markers associated with rice blast resistance genes in an $\mathrm{F}_{2}$ population derived from Pongsu Seribu 2 resistant variety and Mahsuri, a susceptible rice cultivar.

\section{MATERIAL AND METHODS}

\section{Plant materials}

An $\mathrm{F}_{2}$ population derived from a cross between a local rice variety, Pongsu Seribu 2 (resistant variety), and a susceptible rice cultivar, Mahsuri (Figure 1), was genotyped with selected SSR markers associated with blast resistance genes. Pongsu Seribu 2 is a resistant variety that possesses broad-spectrum resistance to blast fungal isolates; it originate from the Malaysian Rice Research Centre, Malaysian Agricultural Research and Development Institute 
(MARDI). Pongsu Seribu 2 was discovered to be resistant to many Malaysian blast pathotypes, similar to the famous donor resistant varieties, including Tadukan from the Philippines and Tetep from Vietnam (Jia et al., 2003). Mahsuri was obtained by crossing Taichung 65 and Mayang Ebos 80 in Malaysia (Yamakawa et al., 1977). Mahsuri has wide adaptability and good eating quality. Unfortunately, this cultivar is very susceptible to blast. Currently, it is used as a check variety for blast screening.

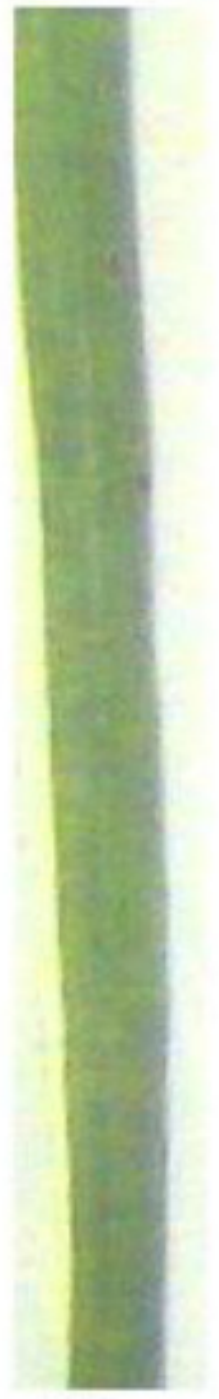

PS2

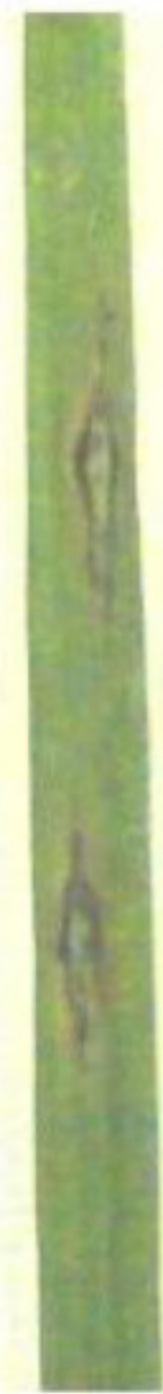

Mh

Figure 1. Rice cultivars Pongsu Seribu 2 (PS2) (resistant) and Mahsuri (Mh) (susceptible) inoculated with pathotype 7.2 of Magnaporthe oryzae. Severe blast lesions are observed in Mh and few lesions in PS2. The photo was taken 10 days after inoculation. 


\section{Genomic DNA isolation}

Total genomic DNA was extracted from fresh frozen leaf tissues of 4-week-old individual $\mathrm{F}_{2}$ and parental plants using the CTAB method, as described by Doyle and Doyle (1990) with some modifications and following the protocol described by McCouch et al. (1988). About $1 \mathrm{~g}$ leaf tissue was ground in liquid nitrogen and transferred to $15 \mathrm{~mL}$ preheated CTAB extraction buffer containing $100 \mathrm{mM}$ Tris-HCl, $\mathrm{pH} 8.0 ; 1.4 \mathrm{M} \mathrm{NaCl} ; 20 \mathrm{mM}$ EDTA, pH 8.0, and supplemented with $30 \mu \mathrm{L} \beta$-mercaptoethanol. Samples were incubated in a water bath at $60^{\circ} \mathrm{C}$ for $1 \mathrm{~h}$ by gently shaking the tubes at 5-min intervals. After incubation, an equal volume of chloroform-isoamyl alcohol $(24: 1, \mathrm{v} / \mathrm{v})$ was added to the mixture, then the tube was gently inverted to homogenize the mixture at room temperature for 2 min prior to centrifugation. The samples were centrifuged at $5000 \mathrm{rpm}$ for $10 \mathrm{~min}$ at $25^{\circ} \mathrm{C}$ using the Centrifuge 5810 (Eppendorf, Germany). The supernatant aqueous layer was transferred to a new $50-\mathrm{mL}$ Falcon tube and 0.6 volume of cold $\left(-20^{\circ} \mathrm{C}\right)$ isopropanol was added to each sample. The mixture was gently inverted and incubated on ice for $30 \mathrm{~min}$. DNA was spooled out from the tube, transferred to a new micro-centrifuge tube and centrifuged at 12,000 rpm for $1 \mathrm{~min}$. The DNA pellet of each sample was washed with $70 \%$ cold ethanol, followed by a quick centrifugation; the supernatant was gently removed and, after drying in air, the DNA was resuspended in $100 \mu \mathrm{L}$ TE buffer $(10 \mathrm{mM}$ Tris-HCl, $\mathrm{pH}$ 8.0, $1 \mathrm{mM}$ EDTA, $\mathrm{pH} 8.0)$. RNA was removed by adding $2 \mu \mathrm{L}(10 \mathrm{~g} / \mathrm{mL})$ RNAse into the dissolved DNA of each sample and incubated for $30 \mathrm{~min}$ at $37^{\circ} \mathrm{C}$. DNA was quantified by using nano-drop spectrophotometry (ND1000 Spectrophotometer). Re-quantification of DNA was performed on $1 \%$ agarose gel electrophoresis using $1 \mathrm{X}$ TAE buffer at $5-8 \mathrm{~V} / \mathrm{cm}$ for $30 \mathrm{~min}$ and visualized under UV light by staining with $0.1 \mu \mathrm{g} / \mathrm{mL}$ ethidium bromide and diluted with sterile distilled water to a concentration of $20 \mathrm{ng}$ for polymerase chain reation (PCR) analysis and kept in a freezer at $-20^{\circ} \mathrm{C}$.

\section{Primers for SSR amplification}

Primer sets of 120 microsatellites were used and selected from the Gramene database (www.gramene.org) related to blast resistance gene (Pi-Genes); it has been mapped by Wu and Tanksley (1993), Akagi et al. (1996), Temnykh et al. (2000), and McCouch et al. (2002). Primer pairs were optimized for PCR to amplify microsatellite loci. Parental varieties were used to identify SSR polymorphism associated with the rice blast resistance gene.

\section{Polymerase chain reaction}

PCR conditions for the SSR markers were as described in Panaud et al. (1996) and McCouch et al. (2002), with the following modifications: the total reaction was scaled down to $12.5 \mu \mathrm{L}$ : containing $40 \mathrm{ng}$ template DNA, $100 \mu \mathrm{M}$ of each dNTP $(0.2 \mathrm{mM}$ each of dATP, dTTP, dGTP and dCTP), $1.5 \mathrm{mM} \mathrm{MgCl}{ }_{2}$, 1X PCR buffer (10 mM Tris-HCl, $50 \mathrm{mM} \mathrm{KCl}, \mathrm{pH}$ 8.3), $1.0 \mu \mathrm{M}$ of each primer and $0.2 \mathrm{U}$ Taq polymerase. PCR amplification was carried out in a thermocycler (PTC-200 Peltier Thermal Cycler DNA Engine) using the following temperature profile: initial denaturation at $94^{\circ} \mathrm{C}$ for 5 min followed by 35 cycles at $94^{\circ} \mathrm{C}$ for $30 \mathrm{~s}, 55^{\circ} \mathrm{C}$ for $30 \mathrm{~s}, 72^{\circ} \mathrm{C}$ for $30 \mathrm{~s}$, and a final extension at $72^{\circ} \mathrm{C}$ for $5 \mathrm{~min}$, followed by rapid cooling 
to $4^{\circ} \mathrm{C}$ prior to analysis. For electrophoretic analysis, the PCR product was mixed with 2.5 $\mu \mathrm{L} 6 \mathrm{X}$ loading dye $(0.2 \%$ bromophenol blue, $0.2 \%$ xylene cyanol dye and $30 \%$ glycerol in a Tris-EDTA buffer) and electrophoresis was run using a 3.0\% agarose gel containing $0.1 \mu \mathrm{g}$ ethidium bromide $\mu \mathrm{L}$ in $1 \mathrm{X}$ TBE buffer $(0.05 \mathrm{M}$ Tris, $0.05 \mathrm{M}$ boric acid, $1 \mathrm{mM}$ EDTA, $\mathrm{pH}$ 8.0). The gel was run at a constant voltage of $90 \mathrm{~V}$ for $1 \mathrm{~h}$ and visualized under UV light, and analyzed using the Bio-Imaging System (Chemi-Genius, USA).

\section{Genotyping for marker segregation}

A total of 320 progenies were genotyped for SSR marker alleles. Alleles at the SSR loci were detected on $3 \%$ agarose gels. Alleles were scored based on the parental bands. A ladder was added with the first load, used to confirm the allele sizes observed in the parental survey. The plants that showed a pattern similar to the resistant parent alleles were scored as " $R$ " and those with a banding pattern similar to the susceptible parent alleles, were scored as "r", and the heterozygous plants were scored as "Rr".

\section{Disease evaluation in $F_{2}$ populations}

To determine segregation patterns of blast resistance, $\mathrm{F}_{2}$ seedlings were evaluated by inoculation with highly virulent pathotype P7.2 of $M$. oryzae. The blast isolate was obtained from the Rice Research Station, MARDI, Seberang Perai. Inoculation of blast pathogen was carried out as described by Chen (2001). Plants were grown in a green house at $25-30^{\circ} \mathrm{C}$ for 2 to 3 weeks, until they reached the four-leaf stage (Filippi and Prahbu, 2001). Twenty-day-old plants, with three or four fully expanded leaves, were inoculated by spraying with $25 \mathrm{~mL}$ aqueous spore suspension onto the leaves until run-off, using an atomizer connected to an air compressor. The blast conidial suspension was adjusted to $1 \mathrm{x}$ $10^{5}$ per $\mathrm{mL}$ with sterilized deionized water. Inoculated plants were incubated in a moisture/ dew chamber and the relative humidity (RH) was maintained at $100 \%$ for $24 \mathrm{~h}$ at $25^{\circ}$ to $28^{\circ} \mathrm{C}$, after which they were placed in the greenhouse (controlled environment) at temperatures ranging from $25^{\circ}$ to $30^{\circ} \mathrm{C}$ (Filippi and Prahbu, 2001). The $\mathrm{RH}$ was maintained at above $90 \%$ by covering them with black netting while under moist jute sacks as well as watering them four to five times during the daytime. Disease assessment was scored 7 days after inoculation. Scoring was carried out based on the Standard Evaluation System (SES) of the International Rice Research Institute (IRRI, 1996) and the standardized protocol of Mackill and Bonman (1992). The blast lesion degrees (LD) were scored as follows: $0=$ no evidence of infection; $1=$ brown specking indicative of an RH response $(<0.5 \mathrm{~mm}$ in diameter); $3=$ brown lesions of $0.5-1.0 \mathrm{~mm}$ wide; $5=$ round to elliptical lesions of $1-3 \mathrm{~mm}$ in diameter (or length) with a grey center; $7=$ spindle shaped lesions with a grey center, and 9 = coalesced type 4 lesions across most of the leaf. For data analysis of the single-gene model, the rice plants showing lesion types 0 and 1 were considered to be resistant $(\mathrm{R})$ and the plants showing lesions type 3 and above were considered to be susceptible $(\mathrm{S})$ to the selected pathotype. A two-gene model was also analyzed by classification of resistance to pathotype P7.2 as R, moderately resistant (MR), moderately susceptible (MS), and S. The plants with lesion scores of 0 and 1 were considered to be R, 3 as MR, 5 as MS, and 7 and 9 as S (Bonman et al., 1989). According to Mendelian principle, the phenotypic segrega- 
tion for a two-gene model is 9:3:3:1 for R:MR:MS:S, respectively. A test for epistasis was carried out by analyzing $\mathrm{F}_{2}$ populations to determine whether they would segregate with a 15(R):1(S) ratio. The plants with disease reaction score of $0,1,3$, and 5 were considered as $\mathrm{R}$, while disease reaction scores of 7 and 9 were considered as $\mathrm{S}$.

\section{Statistical analysis}

Segregation data were analyzed by the chi-square $\left(\chi^{2}\right)$ test. The chi-square analysis for the genotypic and phenotypic ratio was calculated by using the formula, $\chi^{2}=(\mathrm{O}-\mathrm{E})^{2} / \mathrm{E}$, where $\mathrm{O}$ is the observed value and $\mathrm{E}$ is the expected value. For the single-gene model and epistasis, each chi-square value was considered to be significant $(\mathrm{P} \leq 0.05)$ if its value was greater than 3.84, while for two independent genes if it was greater than 7.84 .

\section{RESULTS}

\section{SSR marker survey of parents and $F_{2}$ populations}

Of 120 SSR markers, about $40 \%$ showed clear polymorphism between blast susceptible and resistant parents. Among these, the 23 best polymorphic markers were evaluated on $320 \mathrm{~F}_{2}$ progenies derived from Pongsu Seribu $2 \times$ Mahsuri (Table 1). The patterns of all the markers varied in the segregating population. The banding patterns of microsatellite primer pairs for three polymorphic markers linked with blast Pi genes, RM168, RM8225, and RM1233, for 13 samples along with two parents are shown in Figures 2, 3 and 4, respectively.

\begin{tabular}{|c|c|c|c|c|c|}
\hline \multirow[t]{2}{*}{ SSR markers } & \multicolumn{2}{|c|}{ Primer sequences $\left(5^{\prime}-3^{\prime}\right)$} & \multirow[t]{2}{*}{ Chromosome } & \multirow{2}{*}{$\begin{array}{c}\text { Repeat } \\
\text { motif }\end{array}$} & \multirow{2}{*}{$\begin{array}{l}\text { Expected PCR } \\
\text { product size (bp) }\end{array}$} \\
\hline & F: sequence of forward primer & $\mathrm{R}$ : sequence of reverse primer & & & \\
\hline RM1 & GCGAAAACACAATGCAAAAA & GCGTTGGTTGGACCTGAC & 1 & $(\mathrm{GA})_{26}$ & 113 \\
\hline RM104 & GGAAGAGGAGAGAAAGATGTGTGTCG & TCAACAGACACACCGCCACCGC & 1 & $(\mathrm{GA})_{9}$ & 222 \\
\hline RM428 & AACAGATGGCATCGTCTTCC & CGCTGCATCCACTACTGTTG & 1 & $(\mathrm{AG})_{15}$ & 266 \\
\hline RM228 & CTGGCCATTAGTCCTTGG & GCTTGCGGCTCTGCTTAC & 10 & $(\mathrm{CA})_{6}(\mathrm{GA})_{36}$ & 154 \\
\hline RM244 & CCGACTGTTCGTCCTTATCA & CTGCTCTCGGGTGAACGT & 10 & $(\mathrm{CT})_{4}(\mathrm{CG})_{3} \mathrm{C}(\mathrm{CT})_{6}$ & 163 \\
\hline RM304 & TCAAACCGGCACATATAAGAC & GATAGGGAGCTGAAGGAGATG & 10 & $(\mathrm{GT})_{2}(\mathrm{AT})_{10}(\mathrm{GT})_{33}$ & 160 \\
\hline RM527 & GGCTCGATCTAGAAAATCCG & TTGCACAGGTTGCGATAGAG & 6 & $(\mathrm{GA})_{17}$ & 233 \\
\hline RM6836 & TGTTGCATATGGTGCTATTTGA & GATACGGCTTCTAGGCCAAA & 6 & $(\mathrm{TCT})_{14}$ & 240 \\
\hline RM8225 & ATGCGTGTTCAGAAATTAGG & TTGTTGTATACCTCATCGACAG & 6 & $\mathrm{~A}_{11} \mathrm{~N}(\mathrm{AAG})_{14}$ & 221 \\
\hline RM8226 & TTAGGATACGGCTTCTAGGC & CGTAATTGTTGCATATGGTG & 6 & $(\mathrm{AAG})_{14}$ & 251 \\
\hline RM340 & GGTAAATGGACAATCCTATGGC & GACAAATATAAGGGCAGTGTGC & 6 & $(\mathrm{CTT})_{8} \mathrm{~T}_{3}(\mathrm{CTT})_{14}$ & 163 \\
\hline RM206 & CCCATGCGTTTAACTATTCT & CGTTCCATCGATCCGTATGG & 11 & $(\mathrm{CT})_{21}$ & 147 \\
\hline RM224 & ATCGATCGATCTTCACGAGG & TGCTATAAAAGGCATTCGGG & 11 & $(\mathrm{AAG})_{8}(\mathrm{AG})_{13}$ & 157 \\
\hline RM229 & CACTCACACGAACGACTGAC & CGCAGGTTCTTGTGAAATGT & 11 & $(\mathrm{TC})_{11}(\mathrm{CT})_{5} \mathrm{C}_{3}(\mathrm{CT})_{5}$ & 116 \\
\hline RM287 & TTCCCTGTTAAGAGAGAAATC & GTGTATTTGGTGAAAGCAAC & 11 & $(\mathrm{GA})_{21}$ & 118 \\
\hline RM332 & GCGAAGGCGAAGGTGAAG & CATGAGTGATCTCACTCACCC & 11 & $(\mathrm{CTT})_{5-12-}(\mathrm{CTT})_{14}$ & 183 \\
\hline RM1233 & GTGTAAATCATGGGCACGTG & AGATTGGCTCCTGAAGAAGG & 11 & $(\mathrm{AG})_{15}$ & 175 \\
\hline RM5961 & GTATGCTCCTCCTCACCTGC & ACATGCGACGTGATGTGAAC & 11 & $(\mathrm{CAG})_{8}$ & 129 \\
\hline RM168 & TGCTGCTTGCCTGCTTCCTTT & GAAACGAATCAATCCACGGC & 3 & $\mathrm{~T}_{15}(\mathrm{GT})_{14}$ & 116 \\
\hline RM169 & TGGCTGGCTCCGTGGGTAGCTG & TCCCGTTGCCGTTCATCCCTCC & 5 & $(\mathrm{GA})_{12}$ & 167 \\
\hline RM413 & GGCGATTCTTGGATGAAGAG & TCCCCACCAATCTTGTCTTC & 5 & $(\mathrm{AG})_{11}$ & 79 \\
\hline RM350 & TGATCGTCGCGATTCCCGGC & CCCCACCCTGCGCCTCTCCC & 8 & $(\mathrm{CT})_{10}$ & 208 \\
\hline RM1359 & CTCGCGAGGAAGAAGACAAC & CGCCGGCTGGTTAATTAATC & 4 & $(\mathrm{AG})_{25}$ & 170 \\
\hline
\end{tabular}




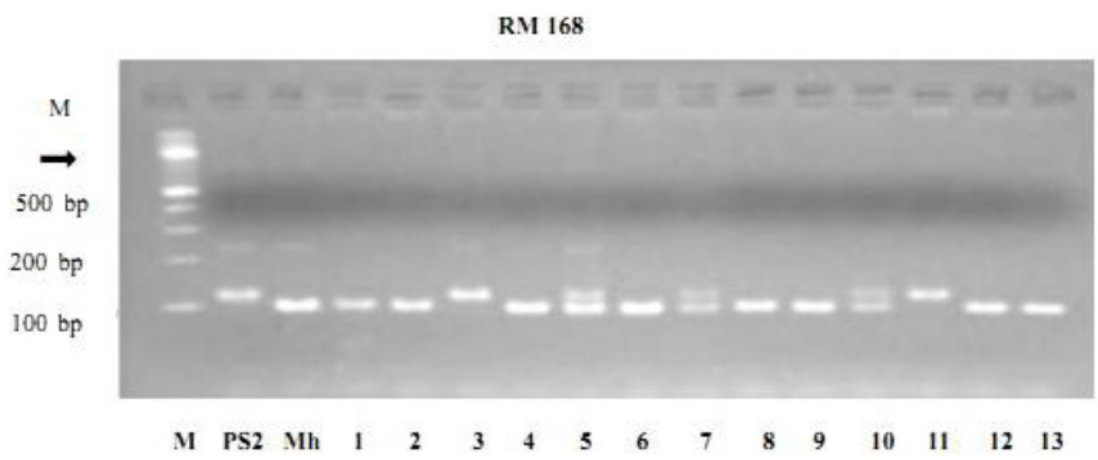

Figure 2. Marker banding patterns in an F2 population of rice derived from Pongsu Seribu $2(\mathrm{PS} 2) \times$ Mahsuri (Mh) for SSR marker RM 168 linked to blast resistance genes. Running on 3\% agarose gel stained with ethidium bromide only 13 samples plus the two parents (their corresponding parents) for each marker are shown. $\mathrm{M}=100$-bp ladder; PS2 = Pongsu Seribu 2; Mh = Mahsuri; lanes $1-13=$ progenies.

\section{RM 8225}

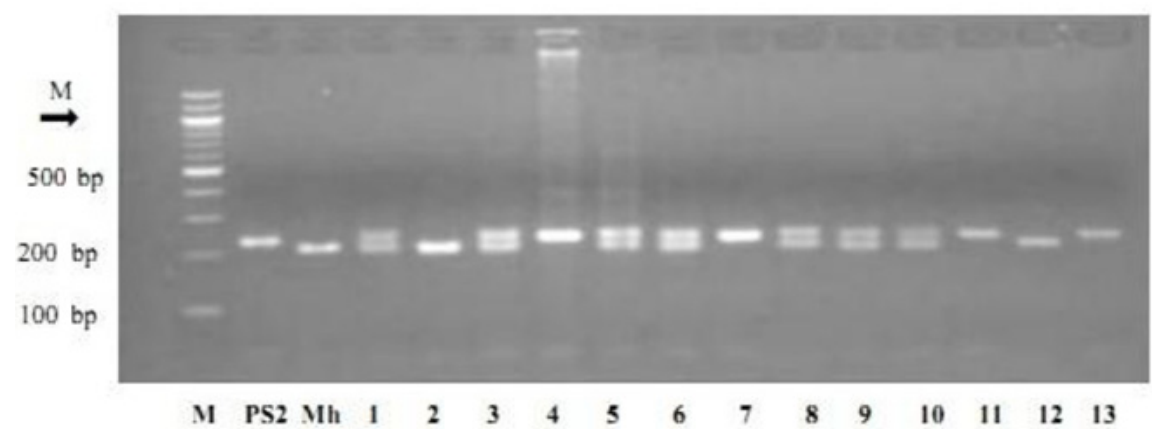

Figure 3. Marker banding patterns in an F2 population of rice derived from Pongsu Seribu 2 (PS2) $\times$ Mahsuri $(\mathrm{Mh})$ for SSR marker, RM 8225 linked to blast resistance genes. Running on 3\% agarose gel stained with ethidium bromide only 13 samples plus the two parents (their corresponding parents) for each marker are shown. $\mathrm{M}=100-\mathrm{bp}$ ladder; PS2 = Pongsu Seribu 2; Mh = Mahsuri; lanes 1-13 = progenies.

\section{RM 1233}

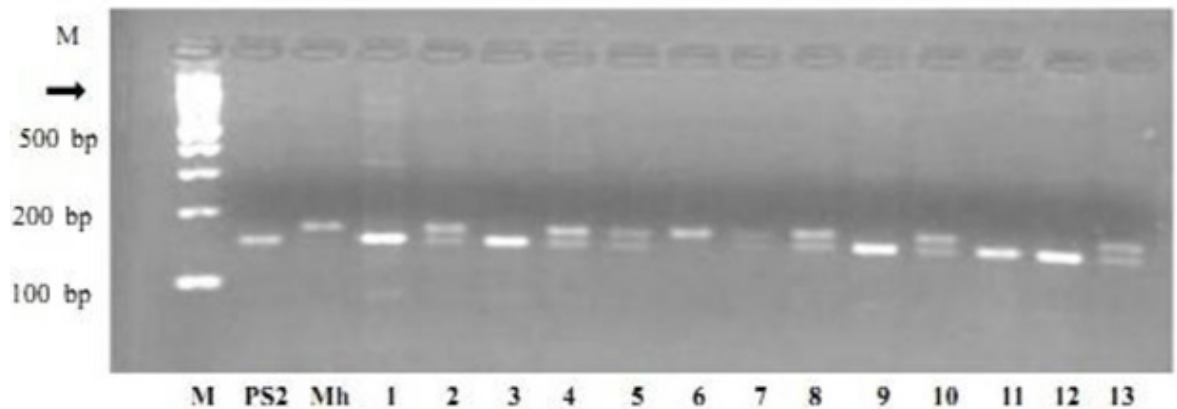

Figure 4. Marker banding patterns in an F2 population of rice derived from Pongsu Seribu 2 (PS2) $\times$ Mahsuri (Mh) for SSR marker RM 1233 linked to blast resistance genes. Running on 3\% agarose gel stained with ethidium bromide only 13 samples plus the two parents (their corresponding parents) for each marker are shown. $\mathrm{M}=100$-bp ladder; PS2 = Pongsu Seribu 2; Mh = Mahsuri; lanes 1-13 = progenies. 


\section{Marker segregation data analysis}

Alleles at the SSR loci were scored based on the parental bands that were amplified as controls along with the $\mathrm{F}_{2}$ individuals. The observed segregation ratio for resistance and susceptibility in $\mathrm{F}_{2}$ lines for 23 polymorphic SSR markers is shown in Table 2. The chi-square $\left(\chi^{2}\right)$ analysis for 11 SSR markers, RM104, RM244, RM6836, RM8225, RM206, RM1233, RM5961, RM168, RM413, RM350, and RM1359, showed a good fit to the expected segregation ratio $(1: 2: 1)$ for a single-gene model $($ d.f. $=1.0, \mathrm{P}<0.05)$. The rest of the markers did not fit the expected segregating Mendelian ratios.

Table 2. Marker analysis in $\mathrm{F}_{2}$ lines derived from the cross between rice varieties Pongsu Seribu $2 \times$ Mahsuri.

\begin{tabular}{|c|c|c|c|c|c|c|}
\hline \multirow[t]{2}{*}{ Markers } & \multirow[t]{2}{*}{ Chromosome } & \multicolumn{3}{|c|}{ Marker analyzed } & \multirow[t]{2}{*}{$\chi^{2}(1: 2: 1)$} & \multirow[t]{2}{*}{ Probability } \\
\hline & & $\mathrm{RR}=\mathrm{R}$ & $\mathrm{Rr}=\mathrm{SG}$ & $\mathrm{rr}=\mathrm{S}$ & & \\
\hline RM1 & 1 & 86 & 138 & 96 & $6.68 * *$ & 0.0354 \\
\hline RM104 & 1 & 90 & 150 & 80 & 1.88 & 0.3906 \\
\hline RM428 & 1 & 93 & 136 & 91 & $7.23 * *$ & 0.0269 \\
\hline RM228 & 10 & 87 & 133 & 100 & $10.17 * *$ & 0.0062 \\
\hline RM244 & 10 & 78 & 166 & 76 & 0.48 & 0.7866 \\
\hline RM304 & 6 & 66 & 160 & 94 & $4.9 *$ & 0.0863 \\
\hline RM527 & 6 & 106 & 144 & 70 & $11.3 * *$ & 0.0035 \\
\hline RM6836 & 6 & 80 & 154 & 86 & 0.68 & 0.7118 \\
\hline RM8225 & 6 & 75 & 154 & 91 & 2.05 & 0.3588 \\
\hline RM8226 & 6 & 89 & 137 & 94 & $6.77 * *$ & 0.0339 \\
\hline RM340 & 6 & 89 & 135 & 96 & $8.12 * *$ & 0.0172 \\
\hline RM206 & 11 & 76 & 156 & 88 & 1.1 & 0.5769 \\
\hline RM224 & 11 & 104 & 144 & 72 & $9.6 * *$ & 0.0082 \\
\hline RM229 & 11 & 68 & 159 & 93 & $3.92 *$ & 0.1409 \\
\hline RM287 & 11 & 98 & 136 & 86 & $8.1 * *$ & 0.0174 \\
\hline RM332 & 11 & 104 & 159 & 57 & $13.82 * *$ & 0.001 \\
\hline RM1233 & 11 & 86 & 147 & 87 & 2.12 & 0.3465 \\
\hline RM5961 & 11 & 86 & 146 & 88 & 2.48 & 0.2894 \\
\hline RM168 & 3 & 77 & 155 & 88 & 1.07 & 0.5857 \\
\hline RM169 & 5 & 92 & 135 & 93 & $7.82 * *$ & 0.02 \\
\hline RM413 & 5 & 72 & 159 & 89 & 1.82 & 0.4025 \\
\hline RM350 & 8 & 73 & 163 & 84 & 0.87 & 0.6473 \\
\hline RM1359 & 4 & 88 & 153 & 79 & 1.12 & 0.5712 \\
\hline
\end{tabular}

$* 0.05$ significance level; $* * 0.01$ significance level. $\mathrm{R}=$ resistant; $\mathrm{S}=$ susceptible; $\mathrm{SG}=$ segregant; $\mathrm{rr}=$ plants with a banding pattern similar to the susceptible parent alleles; $\mathrm{Rr}=$ heterozygous plants. $\chi^{2}=$ the actual value of the chi-square test for resistant/susceptible ratio.

\section{Inheritance of blast resistance in an $F_{2}$ population}

Inheritance studies of blast resistance against the most virulent local pathotype, P7.2 in $\mathrm{F}_{2}$ progenies derived from the same cross, showed that resistance in this population segregated in a 3:1 ratio for plants with resistance and susceptibility (Table 3). The individuals of $\mathrm{F}_{2}$ population showing alleles of RM168 (116 bp), RM8225 (221 bp), RM1233 (175 bp), RM6836 (240 bp), RM5961 (129 bp), and RM413 (79 bp) were resistant to pathotype P7.2.

Phenotypic segregation of the $\mathrm{F}_{2}$ populations treated with pathotype P7.2 of M. oryzae for a two-gene model did not show a good fit to a 9:3:3:1 ratio $\left(\chi^{2}=43.92, \mathrm{P}>0.0001\right)$. This indicates that resistance to blast caused by pathotype 7.2 in $\mathrm{F}_{2}$ populations was most likely not controlled by two genes. The chi-square analysis of epistasis showed that the $\mathrm{F}_{2}$ populations did not segregate in a 15R:1S ratio for resistant versus susceptible plants. Therefore, locus in- 
teraction or epistasis of blast resistance did not occur in the $\mathrm{F}_{2}$ population derived from Pongsu Seribu 2 and Mahsuri.

\begin{tabular}{|c|c|c|c|c|c|}
\hline \multirow[t]{2}{*}{ Generation } & \multicolumn{3}{|c|}{ Pathogenicity assay } & \multirow[t]{2}{*}{$\chi^{2}(3: 1)$} & \multirow[t]{2}{*}{$\mathrm{P}$} \\
\hline & Reaction & Obs. No. & Exp. No. & & \\
\hline \multirow[t]{2}{*}{$\mathrm{F}_{2}$} & $\begin{array}{l}\text { Resistant (R) } \\
\text { Susceptible (S) }\end{array}$ & $\begin{array}{r}227 \\
93\end{array}$ & $\begin{array}{r}240 \\
80\end{array}$ & $\begin{array}{l}0.70 \\
2.11\end{array}$ & \\
\hline & Total & 320 & 320 & 2.81 & 0.1060 \\
\hline
\end{tabular}

d.f. $=1.0 ; \chi^{2}(0.05,1)=3.84$.

\section{DISCUSSION}

In segregation analysis, 11 polymorphic markers clearly showed goodness of fit to the expected segregation ratio for the single-gene model. The segregation ratio was not in agreement with the expected Mendelian ratio for 12 other polymorphic markers. Resistance in the $\mathrm{F}_{2}$ population was inherited in a 3:1 ratio for plants with resistance versus susceptibility. Chi-square tests of data obtained from segregation of resistance of possible different gene models, i.e., two independent gene model and epitasis effect or two locus interactions, showed that blast resistance present in the $F_{2}$ population, specifically for pathotype P7.2, was not segregated into 9:3:3:1 or 15:1 ratios. We conclude that resistance to blast in Pongsu Seribu 2, specifically against pathotype P7.2, is mostly controlled by a single dominant gene. This situation is in agreement with the statement that the ability of a plant to express resistance is also dependent on the genotype of the pathogen. A rice plant cannot be resistant to an isolate of $M$. oryzae unless the pathogen has a gene that makes it virulent to the rice plant. An isolate of $M$. oryzae cannot be avirulent on the rice plant unless the rice plant has genes that make it resistant to that isolate (Ellingboe and Chao, 1994). Several studies have shown that partial resistance can be race specific (Bonman et al., 1989; Talukder et al., 2004; Lopez-Gerena, 2006). Our result is in agreement with a blast research done at IRRI in the Philippines, which indicated that one or two dominant genes present in the cultivars confer complete resistance against each fungal isolate (Yu et al., 1987). Meanwhile, Sharma et al. (2007) reported inheritance studies to determine genetic control of blast resistance in a cross involving the resistant (R) "Laxmi" cultivar and the susceptible (S) "Mahsuri" cultivar. The $\mathrm{F}_{2}$ population segregated into 3R:1S, indicating that resistance in "Laxmi" was governed by a single dominant gene. This was also confirmed by the segregation patterns in the $\mathrm{F}_{3}$ and $\mathrm{F}_{4}$ generations. In another report, the resistance ratios of the subsequent $\mathrm{F}_{2}$ progenies of Indian native rice cultivar Aus373 were governed by dominant alleles at two loci (Pan et al., 1999). Nevertheless, to understand the molecular mechanism of broad-spectrum resistance to rice blast and for further confirmation of the result reported here, additional genetics studies are needed to investigate whether qualitative and quantitative genes affect the level of the resistance in rice variety Pongsu Seribu 2.

The individuals of the $\mathrm{F}_{2}$ population (derived from Pongsu Seribu $2 \times$ Mahsuri) that had the alleles RM168 (116 bp), RM8225 (221 bp), RM1233 (175 bp), RM6836 (240 bp), RM5961 (129 bp), and RM413 (79 bp) were resistant to pathotype P7.2. The blast resistant plants had the alleles of these six SSR markers. This finding has potential for use in markerassisted selection programs and confirmation of blast resistance genes to develop rice cultivars with durable blast resistance in Malaysian rice breeding programs. 


\section{CONCLUSIONS}

Twenty-three polymorphic markers were used for the identification of segregation ratios in $\mathrm{F}_{2}$ population. Chi-square analyses of $11 \mathrm{SSR}$ markers showed an expected segregation ratio of 1:2:1, inherited in simple Mendelian fashion. Phenotypic data based on disease reaction of resistance and susceptibility to blast pathotype P7.2 also segregated in a 3:1 (R:S) ratio in the $F_{2}$ population. Therefore, resistance to blast pathotype P7.2 in Pongsu Seribu 2 is more likely controlled by a single nuclear gene. The plants resistant to blast pathotype P7.2 from $\mathrm{F}_{2}$ lines had genotypes with SSR markers RM168, RM8225, RM1233, RM6836, RM5961, and RM413; these markers could be used for marker-assisted selection.

\section{ACKNOWLEDGMENTS}

We thank the Malaysian Nuclear Agency, Molecular Biology Group, for providing markers and the Malaysian Rice Research Centre, MARDI, for helpful discussions and greenhouse facilities required for this research.

\section{REFERENCES}

Akagi H, Yokozeki Y, Inagaki A and Fujimura T (1996). Microsatellite DNA markers for rice chromosomes. Theor. Appl. Genet. 93: 1071-1077.

Berruyer R, Adreit H, Milazzo J, Gaillard S, et al. (2003). Identification and fine mapping of Pi33, the rice resistance gene corresponding to the Magnaporthe grisea avirulence gene ACE1. Theor. Appl. Genet. 107: 1139-1147.

Bonman JM, Bandong JM, Lee YH, Lee EJ, et al. (1989). Race-specific partial resistance to blast in temperate japonica rice cultivars. Plant Dis. 73: 496-499.

Bres-Patry C, Loreux M, Clément G, Bangratz M, et al. (2001). Heredity and genetic mapping of domestication-related traits in a temperate japonica weedy rice. Theor. Appl. Genet. 102: 118-126.

Chauhan S, Farman ML, Zhang HB and Leong A (2002). Genetic and physical mapping of a rice blast resistance locus, PiCO39(t), that corresponds to the avirulence gene AVR1-CO39 of Magnaporthe grisea. Mol. Genet. Genomics 267: 603-612.

Chen H (2001). Population Structure of Pyricularia grisea from Central and Southern China and Comparative Mapping of QTL for Blast- and Bacterial Blight-Resistance in Rice and Barley (in Chinese). Ph.D. dissertation, Huazhong Agriculture University, Wuhan, China.

Cho YG, Ishii T, Temnykh S, Chen X, et al. (2000). Diversity of microsatellites derived from genomic libraries and GenBank sequences in rice (Oryza sativa L.). Theor. Appl. Genet. 100: 713-722.

Correa-Victoria FJ, Tharreau D, Martínez C, Vales M, et al. (2002). Combinaciones de genes en arroz para el desarrollo de resistencia durable a Pyricularia grisea en Colombia. Fitopatología Colombiana 26: 47-54.

Doyle JJ and Doyle JL (1990). Isolation of plant DNA from fresh tissue. Focus 12: 13-15.

Ellingboe AH and Chao CCT (1994). Genetic Interactions in Magnaporthe grisea that Affect Cultivar Specific Avirulence/Virulence in Rice. In: Rice Blast Disease (Zeigler RS, Leong SA and Teng PS, eds.). CAB International, Wallingford, 51-64.

Filippi MC and Prahbu AS (2001). Phenotypic virulence analysis of Pyricularia grisea isolates from Brazilian upland rice cultivars. Pesq. Agropec. Bras. 36: 27-35.

Fjellstrom R, McClung A, Shank AR, Marchetti MA, et al (2002). Progress on Development of Microsatellite Markers Associated With Rice Blast Resistance Genes. Proceedings of the 29th Rice Technical Working Group Meeting. The Texas Agricultural Experiment Station, College Station, 43-44.

Harrington S (2000). A survey of genetic diversity of eight AA genome species of Oryza using microsatellite markers. MS thesis Cornell University, Ithaca.

Hittalmani S, Foolad MR, Mew T, Rodriguez RL, et al. (1995). Development of a PCR-based marker to identify rice blast resistance gene, Pi-2(t), in a segregation population. Theor. Appl. Genet. 91: 9-14.

IRRI (1996). Standard Evaluation System for Rice. 4th edn. The International Network for Genetic Evaluation of Rice, Genetic Resources Center. International Rice Research Institute, Manila, 52. 
Jia Y, Bryan GT, Farrall L and Valent B (2003). Natural variation at the Pi-ta rice blast resistance locus. Phytopathology 93: $1452-1459$

Koizumi S (2007). Durability of resistance to rice blast disease. JIRCAS Working Rep. 53: 1-10.

Liu B, Zhang S, Zhu X, Yang Q, et al. (2004). Candidate defense genes as predictors of quantitative blast resistance in rice. Mol. Plant Microbe Interact. 17: 1146-1152.

Lopez-Gerena L (2006). Mapping QTL Controlling Durable Resistance to Rice Blast in Cultivar Oryza llanos 5. Ph.D. thesis, Kansas State University, Manhattan, KS, USA.

Mackill DJ and Bonman JM (1992). Inheritance of blast resistance in near-isogenic lines of rice. Phytopathology 82: 746-749.

McCouch SR, Kochert G, Yu ZH, Wang ZY, et al. (1988). Molecular mapping of rice chromosomes. Theor. Appl. Genet. 76: 815-829.

McCouch SR, Teytelman L, Xu Y, Lobos KB, et al. (2002). Development and mapping of 2240 new SSR markers for rice (Oryza sativa L.). DNA Res. 9: 199-207.

Moncada P, Martinez CP, Borrero J, Châtel M, et al. (2001). Quantitative trait loci for yield and yield components in an Oryza sativa $\mathrm{x}$ Oryza rufipogon $\mathrm{BC}_{2} \mathrm{~F}_{2}$ population evaluated in an upland environment. Theor. Appl. Genet. 102: 41-52.

Naqvi NI and Chattoo BB (1996). Development of a sequence characterized amplified region (SCAR) based indirect selection method for a dominant blast-resistance gene in rice. Genome 39: 26-30.

Ou SH (1980). Pathogen variability and host resistance in rice blast disease. Ann. Rev. Phytopathol. 18: 167-187.

Pan QH, Wang L and Tanisaka T (1999). A new blast resistance gene identified in the Indian native rice cultivar Aus373 through allelism and linkage tests. Plant Pathol. 48: 288-293.

Panaud O, Chen X and McCouch SR (1996). Development of microsatellite markers and characterization of simple sequence length polymorphism (SSLP) in rice (Oryza sativa L.). Mol. Gen. Genet. 252: 597-607.

Sallaud C, Lorieux M, Roumen E, Tharreau D, et al. (2003). Identification of five new blast resistance genes in the highly blast-resistant rice variety IR64 using a QTL mapping strategy. Theor. Appl. Genet. 106: 794-803.

Sharma RC, Shrestha SM and Pandey MP (2007). Inheritance of blast resistance and associated microsatellite markers in rice cultivar "Laxmi". J. Phytopathol. 155: 749-753.

Talukder ZI, Tharreau D and Price AH (2004). Quantitative trait loci analysis suggests that partial resistance to rice blast is mostly determined by race-specific interactions. New Phytol. 162: 197-209.

Temnykh S, Park WD, Ayers N, Cartinhour S, et al. (2000). Mapping and genome organization of microsatellite sequences in rice (Oryza sativa L.). Theor. Appl. Genet. 100: 697-712.

Wang GL, Mackill DJ, Bonman JM, McCouch SR, et al. (1994). RFLP mapping of genes conferring complete and partial resistance to blast in a durably resistant rice cultivar. Genetics 136: 1421-1434.

Wu KS and Tanksley SD (1993). Abundance, polymorphism and genetic mapping of microsatellites in rice. Mol. Gen. Genet. 241: 225-235.

Yamakawa Y, Fuji K, Kawakami J and Samoto S (1977). Studies on breeding Malinja, Mahsuri and Bahagia, new rice varieties for double cropping in Malaysia. Jpn. J. Trop. Agric. 21: 40-42.

Yu ZH, Mackill DJ and Bonman JM (1987). Inheritance of resistance to blast in some traditional and improved rice cultivars. Phytopathology 77: 323-326.

Zhu M, Wang L and Pan Q (2004). Identification and characterization of a new blast resistance gene located on rice chromosome 1 through linkage and differential analyses. Phytopathology 94: 515-519.

Zou JH, Pan XB, Chen ZX, Xu JY, et al. (2000). Mapping quantitative trait loci controlling sheath blight resistance into rice cultivars (Oryza sativa L.). Theor. Appl. Genet. 101: 569-573. 